\title{
Peripheral B lymphocyte tolerance
}

\author{
Amanda Gavin, Djemel Aït-Azzouzene, Annica Mårtensson, Bao Duong, Laurent Verkoczy, José Luis Skog, \\ Patrick Skog and David Nemazee \\ Department of Immunology, and Macromolecular Structure and Chemistry Program, The Scripps Research \\ Institute, La Jolla, CA, USA \\ (Received for publication on February 9, 2004)
}

\begin{abstract}
This lecture discusses two interrelated topics, B cell tolerance in the peripheral immune system and BAFF. Using the 3-83 antibody transgenic mouse bred to mice carrying cognate antigen in the liver, we previously found that clonal elimination drastically reduced the precursor frequency of autoreactive cells. The consensus model to explain this tolerance is the 2-signal hypothesis, which proposes that in the absence of $T$ cell help BCR stimulation is a negative signal for $B$ cells. However, this model fails to explain how these same B cells can respond to T-independent type II (TI-2) antigens, raising the question of how they distinguish TI-2 antigens from multimeric self determinants. We propose that B cells use NK-like missing self recognition to provide the needed specificity, as foreign antigens are unlikely to carry self markers. The model has implications for the evolution of the immune system, B lymphocyte signaling, tissue specificity of autoimmunity, and microbial subversion of the immune system. Overexpression of the critical B cell survival cytokine BAFF/BLyS has been associated with autoimmunity. We have discovered a novel splice isoform that regulates BAFF activity and may play a role in limiting B cell activity. The novel form, called $\triangle B A F F$, is able to heteromultimerize with normal BAFF and can suppress receptor binding and proteolytic release from the cell surface. Preliminary studies from transgenic mice overexpressing wild type or $\triangle \mathrm{BAFF}$ are consistent with a possible regulatory role for $\triangle \mathrm{BAFF}$, raising the possibility that the relative expression levels of BAFF and $\triangle$ BAFF regulates tolerance. (Keio J Med 53 (3): 151-158, September 2004)
\end{abstract}

Key words: antibody, BAFF, TNF13B, inhibitory signaling, tolerance, B lymphocyte

\section{Introduction}

$A$ new theory of self/non-self discrimination in mature $B$ cells

A coherent theory to explain mature $\mathrm{B}$ cell responsiveness and tolerance does not exist. A number of lines of evidence indicate that mature B cells are tolerizable. The consensus model to explain this tolerance is the 2signal hypothesis, ${ }^{1}$ which proposes that in the absence of T cell help BCR stimulation is a negative signal for B cells, leading to death or functional inactivation. However, these same B cells can respond to T-independent type II (TI-2) antigens, which have the properties of high multivalency and an absence of $\mathrm{T}$ cell determinants. (TI-2 antigens by definition lack intrinsic mitogenicity and therefore likely do not activate toll-like receptors.) Indeed, responses to TI-2 antigens can occur normally in $\mathrm{T}$ cell deficient mice. These considerations raise the question of how B cells can distinguish TI-2 antigens from multimeric self determinants.

A competing alternative to the 2-signal model, initially suggested by Lederberg, is that tolerance sensitivity of B cells is dependent on the age of the individual; cells from immature individuals are tolerance sensitive, whereas those of adults are activatable only. Work of several laboratories has indeed indicated that recently formed splenic B cells or neonatal B cells may be especially susceptible to tolerance induction. ${ }^{2} \mathrm{Un}$ like newly formed bone marrow B cells, ${ }^{3-5}$ these cells do not appear to undergo efficient receptor editing, but are tolerized through an apoptotic process. ${ }^{6}$ In addition, the ability of B cells to respond to TI-2 antigens is acquired relatively slowly after birth. ${ }^{7}$ While transi-

Presented at the 1338th Meeting of the Keio Medical Society in Tokyo, December 12, 2003.

Reprint requests to: Dr. David Nemazee, The Scripps Research Institute, Mail drop IMM-29, 10550 N. Torrey Pines Rd., La Jolla, CA 92037, USA, email: nemazee@scripps.edu 


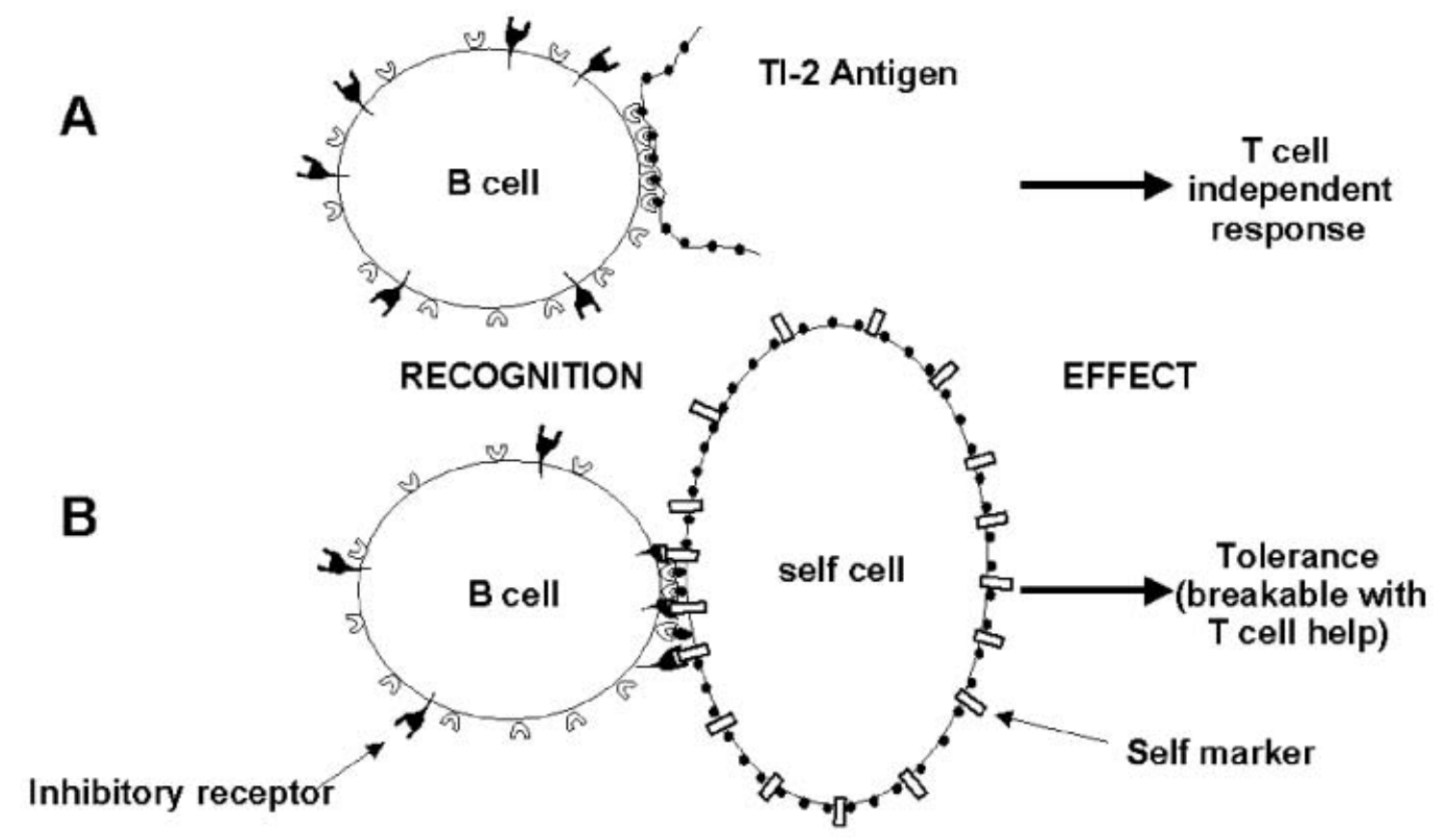

Fig. 1 TI-2 Ags (A) may be distinguished from self (B) by a second marker on self cells. Receptors for the putative second signal could be expressed by soluble factors in the plasma, by putative non-T-cell leukocyte "helpers," or, as indicated here, by the B-cell itself.

tional B cells are more easily tolerized in some experimental situations, mature B cells are clearly tolerizable in vivo, at least in the case of some experimental ligands such as anti-IgD, lysozyme or MHC class I. ${ }^{8-13}$ Given that these tolerizable cells are able to respond to TI-2 antigens, despite the high multivalency of TI-2 antigens and their ability to evoke antibody responses even in the total absence of T cells, ${ }^{14-15}$ it is not clear how TI-2 antigens avoid inducing tolerance and promote activation. In an attempt to resolve this paradox, we have recently proposed the hypothesis that B cells use NKlike missing self recognition to provide the self/non-self discrimination needed to distinguish foreign TI-2 antigens from multivalent self. ${ }^{16}$

"Missing self" recognition is believed to be an important aspect of natural killer (NK) cell signaling. ${ }^{17}$ In NK cells, several receptors are expressed that can stimulate activation of killer function. ${ }^{18}$ These activatory receptors are counteracted by the signaling of more numerous inhibitory receptors. Both activating and inhibitory receptors often recognize MHC class I molecules or related structures. Because of the balance of signals mediated by these receptors, NK cells can be activated under physiological conditions by target cells that lose the expression of a subset of self MHC molecules. This is the basis for such phenomena as hybrid resistance, which is the ability of an F1 hybrid of two inbred strains to reject parental bone marrow grafts through NK-mediated killing. NK recognition is thought to be important for killing of infected or defective host cells, which may lose MHC class I expression as part of a microbial strategy or tumor selection to hide from the CD8 cytotoxic $T$ cells of the adaptive immune system.

As illustrated in Fig. 1, we propose that unlike foreign antigens, self antigens, even those that are displayed in a multimeric array, are associated with one or more widely expressed "self markers" that are capable of stimulating a B cell's inhibitory receptors. Putative self markers would include particular carbohydrate moieties, such as Sia $2-6 \mathrm{Gal} \beta 1-4 \mathrm{GlcNAc}$, the widely expressed host ligand for the B cell-restricted inhibitory receptor CD22. Another established class of self markers is the MHC class I antigens; B cells carry at least one cell surface inhibitory receptor with apparent reactivity to MHC class I molecules, PirB, but its functional significance is unknown. Interestingly, both PirB and CD22 genes have strong homology to NK inhibitory receptors (KIRs) and their genes are located in the genome adjacent to the major KIR homology cluster in both human (chr 19q13) and mouse (chr 7), within the leukocyte receptor cluster (LRC). ${ }^{19}$ Upon activation, PirB and CD22 proteins are phosphorylated at immunoreceptor tyrosine inhibitory motifs (ITIMs; consensus $[\mathrm{L} / \mathrm{I} / \mathrm{V} / \mathrm{S}] \mathrm{xYxx}[\mathrm{L} / \mathrm{V}])$ and recruit the tyrosine phosphatase SHP-1, ${ }^{20-23}$ a mode of action essentially identical to the authentic NK inhibitory receptors. ${ }^{24}$ Other B cell receptors with inhibitory function also map to the LRC region, including LAIR and CD66a. ${ }^{19}$ Additional in- 
hibitory receptors on B cells that contain ITIM motifs and recruit SHP-1, SHP-2 or SHIP-1 phosphatase activities include PD-1, Fc $\gamma$ RIIb, CD72, CD31 and additional members of the FcR superfamily. ${ }^{25-30}$ Therefore, B cells express a diversity of inhibitory receptors similar to those of $\mathrm{NK}$ cells that may participate in "missing self" recognition.

In contrast to their expression of a multiplicity of NK-like inhibitory receptors, B cells do not appear to express any NK-like activatory receptor except the BCR itself. Activatory receptors on NK cells are similar to BCR and TCR in their modes of intracellular signaling. Like the antigen receptors, activatory NK receptors do not have intrinsic signaling function; they are transported to the plasma membrane with signal transducer proteins. ${ }^{18}$ The transducers themselves are small dimeric transmembrane proteins with conserved cytoplasmic immunoreceptor associated tyrosine activatory motifs (ITAMS); consensus: [D/E] $x x Y x x[L /$ I] $\operatorname{xxxxxxxYxx[L/I].~}{ }^{31}$ These ITAM motifs are sites of tyrosine phosphorylation and recruitment of ZAP70 and or syk protein tyrosine kinases. Signal transducers for $\mathrm{T}$ cells, NK cells, and myeloid cells include CD3 $\zeta, \gamma, \delta, \varepsilon, \mathrm{DAP} 12$ and FceRI $\gamma$. B cells lack these transducers, but express the related heterodimer $\operatorname{Ig} \alpha / \beta$. Interestingly, like the NK cell ITAM-containing transducer DAP12, Ig $\alpha$ is encoded near the KIR locus at 19q13.2. $\operatorname{Ig} \alpha$ and $\operatorname{Ig} \beta$ are required both for B cell antigen receptor transport to the plasma membrane and coupling of antigen recognition to the signaling machinery of the cell through cytoplasmic ITAM motifs. ${ }^{31}$

A common feature of activatory receptors is the presence in the transmembrane region of polar or charged amino acid residues (usually $\mathrm{K}$ or R) that interact with a residue of opposite charge (D or E) in a chain of one of the associated transducers. ${ }^{18^{-31}} \mathrm{~A}$ consequence of this design is that expression of functional activatory receptors is restricted by transducer expression and specificity of association. Because $\operatorname{Ig} \alpha$ and $\operatorname{Ig} \beta$ do not appear to directly associate with activatory receptors other than sIg (nor to dimerize with other transducers), the lack of expression in B cells of transducers besides Ig $\alpha / \beta$ insures that $B$ cells cannot use nonimmunoglobulin activatory receptors, even those that are expressed inside the cells, such as PirA. ${ }^{32}$ In contrast, NK and myeloid cell types express multiple transducers that convey signals from a broader array of receptors. For example, NK cells express $\mathrm{CD} 3 \zeta$ and FceRI $\gamma$ in addition to DAP12. Some activatory receptors, such as NKp46, interact with all of these transducers, while others associate solely with particular homodimers of DAP12 (human KIR2DS) or FceRI $\gamma$ (mouse NKR-PI) ${ }^{18}$; NKp46 can also signal through $\mathrm{CD} 3 \zeta$-FceRI $\gamma$ heterodimers. In any case, the suppression by $\mathrm{B}$ cells of alternative signal transducers along

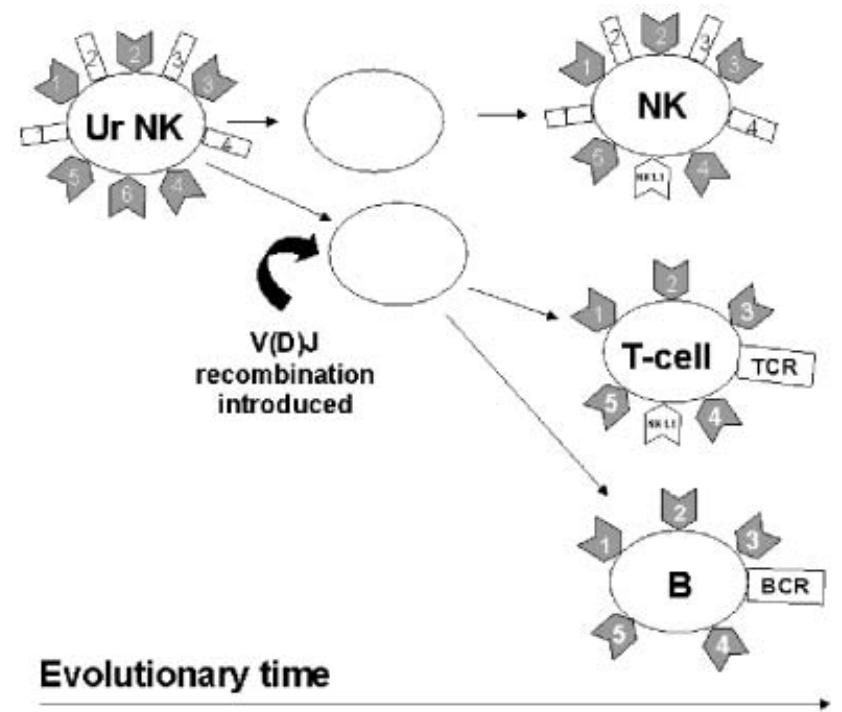

Fig. 2 Hypothetical evolutionary progression differentiating lymphocyte function from its primordial NK activity, to NK and adaptive lymphocyte subsets. Shapes in gray represent inhibitory receptors, those in white, activatory receptors. The model suggests that with the invention of $\mathrm{V}(\mathrm{D}) \mathrm{J}$ recombination at a midpoint in evolution, a subset of lymphocytes discontinued expression of most or all nonrearranging activatory receptors, increasingly focussing on the rearranging activatory receptors $\mathrm{BCR}$ or $\mathrm{TCR}$, while retaining multiple inhibitory receptors.

with the specificity of $\operatorname{Ig} \alpha / \beta$ for association with $\operatorname{sIg}$ appears to insure that a single type of activatory receptor, the $\mathrm{BCR}$, is functional in $\mathrm{B}$ cells.

We therefore propose that in the evolution of the adaptive immune system, $\mathrm{B}$ and $\mathrm{T}$ lymphocytes suppressed expression of innate activatory receptors after the invention of $\mathrm{V}(\mathrm{D}) \mathrm{J}$ recombination, but retained the recombining activatory receptor, along with a significant collection of inhibitory receptors (Fig. 2). One vestige of the proposed $\mathrm{NK}$ origin of lymphocytes is the focus of NK and CD8 T cells on similar MHC class I antigens. A second vestige is the continued expression on a subset of $\mathrm{T}$ cells of the NK activatory receptor NK1.1, which in part defines the NKT cell. ${ }^{33}$ (Upon activation, CD8 cells express a different type of NK receptor associated with the PI3K-recruiting adapter DAP10). ${ }^{34}$ This hypothesis may also help explain odd NK-like features sometimes seen in lymphocytes that promote monoallelic distribution of receptors, such as parental imprinting of the PirB gene. ${ }^{35}$

The notion that $\mathrm{B}$ cells express inhibitory receptors that recognize widely expressed self ligands has numerous implications for immune tolerance and autoimmunity. It is well known that tissues protect themselves from the toxic effects of antibody-mediated complement activation by expressing various regulators of the complement system, such as CD46, CD55 and 
CD35; such inhibition works at the effector phase of antibody responses. ${ }^{36} \mathrm{We}$ suggest that the role of self marker expression by tissues is in part to suppress the initiation phase of such antibody responses through engagement of inhibitory receptors on B cells.

However, tissues may differ in their expression levels of self markers because there are likely to be multiple self markers and cognate receptors involved in the tolerance process. This heterogeneity, coupled with allelic variation in self markers such as MHC class I molecules, may lead to a situation in which in certain individuals particular tissues are more vulnerable than others to a breakdown in tolerance. This target tissue component of immune tolerance may explain how even general defects in lymphocytes can lead to tissue specific autoantibody disease. ${ }^{37} \mathrm{~A}$ second hypothetical contributor to autoantibody disease could be aberrant expression of non-BCR activatory receptors on B cells. For example, aberrant expression of FceRI $\gamma$ and FcyRIII in mature B cells is predicted to result in B cell hyperreactivity. Interestingly, these receptors are expressed by early progenitors of $\mathrm{T}$ and $\mathrm{B}$ cells, but are normally turned off with maturation. ${ }^{38}$

Pathogenic microbes have evolved means to suppress antibody responses. One way they can do so is to produce ligands for inhibitory receptors. The human cytomegalovirus is known to produce a pseudo MHC class I ligand UL18 that engages not only NK inhibitory receptors, but also the B cell inhibitory receptor ILT2, the human homologue of PirB. ${ }^{39-40} \mathrm{~B}$ cells and phagocytes recognize sialic acid moieties on self cells using a number of inhibitory receptors of the so called Siglec family. ${ }^{39}$ B cells may express as many as 5 different Siglecs, including CD22. ${ }^{39}$ Because the ability to produce sialic acids is a relatively recent evolutionary invention, lacking in most non-deuterostome organisms, it is significant that several pathogenic bacteria have independently evolved or captured the enzymatic machinery to do so from their hosts. ${ }^{39}$ This bacterial adaptation should suppress antibody responses early in infection, prior to the development of robust $\mathrm{T}$ cell help. Another potential way that microbes could perturb the B cell system is to introduce activatory signaling that is independent of the BCR. This is known to occur in the case of two viruses, Epstein-Barr virus of humans and Bovine leukemia virus, which encode ITAM-containing proteins that can promote cell activation, growth and survival of infected cells. ${ }^{41}$ Such dysregulation probably promotes $\mathrm{B}$ cell neoplasia.

\section{The regulation of $B$ cell survival by $B A F F$}

In the preceding section, we have proposed that $\mathrm{B}$ cell recognition of self by inhibitory receptors, a cell intrinsic mechanism, facilitates the self/non-self dis-
Table 1 Genes Implicated in B Cell Tolerance or Autoimmunity

\begin{tabular}{ll}
\hline \hline B cell intrinsic & References \\
Fas & $(59)$ \\
Cr2 (CD21/CD35) & $(60,61)$ \\
CD40 & $(62,63)$ \\
Fc $\gamma$ RII & $(64)$ \\
Lyn & $(65-67)$ \\
SHP-1 & $(68,69)$ \\
CD22 & $(70,71)$ \\
Bcl-2 & $(72)$ \\
Bim & $(73,74)$ \\
TLR9 & $(75)$ \\
TACI & $(76)$ \\
B cell extrinsic & $(77-79)$ \\
FasL & $(80,81)$ \\
Complement C1q, C4 & $(63,82-84)$ \\
CD40L & $(62,85,86)$ \\
IL-4 & $(50,87,88)$ \\
BAFF & $(89)$ \\
Tlr4 (LPS) & \\
\hline
\end{tabular}

crimination. The outcome of BCR signaling leading to B cell anergy, activation, survival or death will reflect thresholds of positive and negative signals, along with extrinsic signals that shift these thresholds. Table 1 lists genes expressed in B cells or non-B cells whose overexpression or deficiency is implicated in promoting autoimmunity and breakdown in B cell self-tolerance. In transgenic models where autoreactive $B$ cells have been studied, the fate of autoreactive cells is dependent on the presence of competing, non-autoreactive B cells, indicating that $\mathrm{B}$ cells compete for a limiting survival factor. $^{42-43}$ As we discuss below, a key B cell survival factor whose overexpression is implicated in humoral autoimmunity is BAFF.

Most $B$ cells require at least two signals to survive in the peripheral immune system: intrinsic expression of BCR (i.e., activatory receptor) on the cell surface ${ }^{44}$ and extrinsic availability of the TNF family cytokine BAFF ${ }^{45}$ Furthermore, BCR and BAFF signaling are also important in the TI-2 antibody response. ${ }^{46,47}$ BAFF overexpression in vivo promotes autoimmune lupuslike disease and potentiates antibody responses. ${ }^{4-50}$ On the other hand, mice deficient in BAFF or the BAFF receptor (BAFF-R) lack long-lived follicular B cells and are hyporesponsive to immunization and germinal center maturation. ${ }^{48,51-53}$ BAFF also interacts with two other receptors, TACI and BCMA, which are also able to bind to APRIL, BAFF's closest homologue. Importantly, treatment of lupus-prone mice or a mouse model of collagen-induced arthritis with soluble Fc fusion proteins of TACI, which binds to BAFF, can reduce disease incidence and severity. ${ }^{51}$ On a normal, non-autoimmune background, short-term treatment 

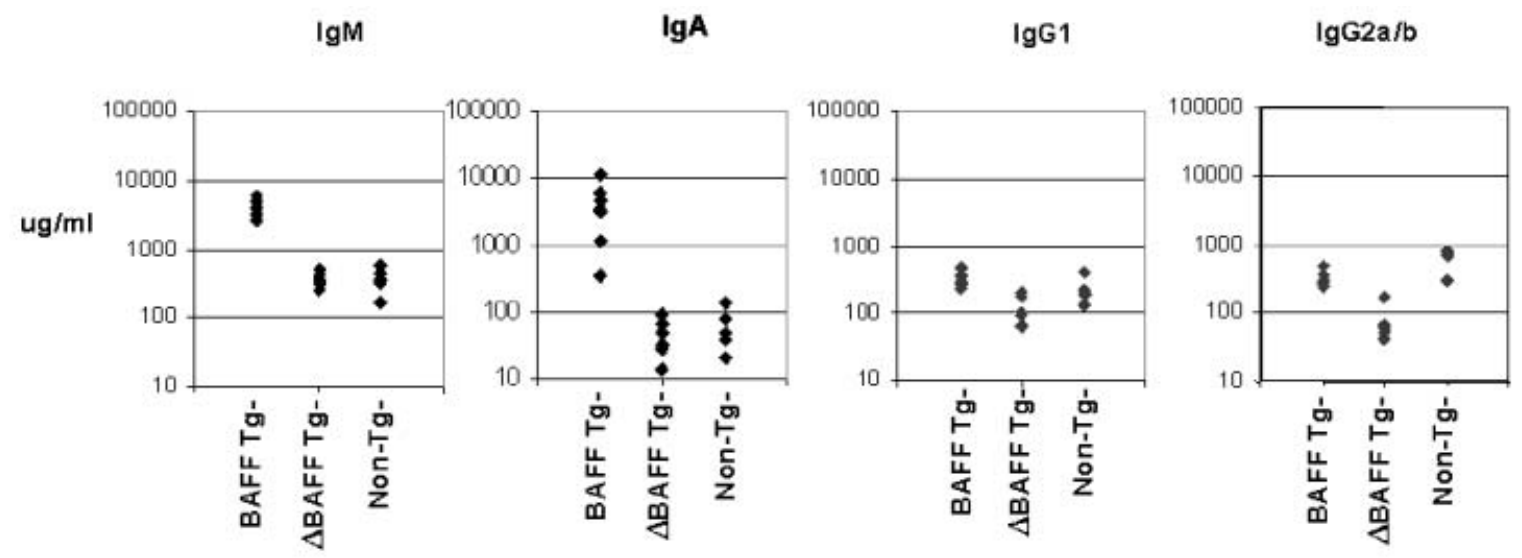

Fig. 3 BAFF transgenic ( $\mathrm{Tg}$ ) mice, but not $\triangle \mathrm{BAFF}$ transgenics, have preferential augmentation of serum IgA levels. Independent male founder mice transgenic for BAFF, $\triangle \mathrm{BAFF}$, or non-Tg controls were tested for serum levels of $\operatorname{IgM}, \operatorname{IgA}, \operatorname{IgG} 1$, and $\operatorname{IgG} 2 \mathrm{a} / \mathrm{b}$.

with BCMA-Fc fusion protein reduced $\mathrm{B}$ cell numbers by two-fold. ${ }^{54}$ Because overexpression or underexpression of BAFF has pathogenic consequences, it is likely that natural antagonists of BAFF action exist.

We recently identified a novel splice isoform of BAFF that exists in both mouse and human. ${ }^{55}$ This form, which is called $\triangle \mathrm{BAFF}$ because it lacks a 57-bp exon, appears to be abundant in quiescent macrophages, while the full-length form predominates in activated macrophages, in which total BAFF levels are greatly induced. Furthermore, $\triangle \mathrm{BAFF}$ can assemble disulfide-linked complexes both with itself and with wild type BAFF. Interestingly, unlike full length BAFF, $\triangle \mathrm{BAFF}$ fails to be efficiently cleaved from the cell membrane. These features, along with the ability of $\triangle \mathrm{BAFF}$ coexpression to limit BAFF bioactivity in a mouse model system, suggest that $\triangle \mathrm{BAFF}$ may play a role in limiting antibody, and autoantibody, responses. $\triangle \mathrm{BAFF}$ may modulate BAFF activity by heterotrimerizing with newly made BAFF to affect receptor specificity or potency, or by preventing efficient release of BAFF from the plasma membrane. Alternatively, or in addition, $\triangle \mathrm{BAFF}$ may heterotrimerize with other TNF family molecules, such as APRIL, which may suppress B cell response or survival through TACI or BCMA signaling. We have begun to probe these possibilities using a transgenic overexpression strategy.

\section{Method}

Transgenic constructs were generated by introducing BAFF or $\triangle \mathrm{BAFF}$ cDNA sequences downstream of a $2.9 \mathrm{~kb}$ human CD68 promoter. ${ }^{56}$ The human CD68 promoter construct has been used in transgenic mice to generate myeloid specific expression. ${ }^{56}$ Vector sequences were removed and isolated insert DNA was microinjected into $[(\mathrm{DBA} / 2 \mathrm{XC} 57 \mathrm{~B} 16 / \mathrm{J}) \mathrm{F} 1 \mathrm{X} \quad(\mathrm{C} 3 \mathrm{H} /$
HeJXC57B16/J)F1] zygotes. Young adult mice were analyzed for plasma immunoglobulins by solid phase ELISA assay. Flow cytometry analysis was used to quantify the numbers of B lymphocyte subsets in the lymphoid organs of young adult offspring of founder mice bred to C57B16/J. A detailed description of the transgene constructs and transgenic mouse characterization will be presented elsewhere (Gavin, et al. in preparation).

\section{Results}

Disparate in vivo biological effects of $B A F F$ and $\triangle B A F F$

We have compared the in vivo functions of BAFF and $\triangle \mathrm{BAFF}$ in a series of transgenic mice expressing BAFF or $\triangle \mathrm{BAFF}$ under the control of the human CD68 promoter, which drives expression in myeloid and dendritic cells, where BAFF is normally expressed. ${ }^{56}$ As shown in Fig. 3, several independent founder lines carrying BAFF transgenes have roughly 100 -fold increased levels of IgA, but only 10 fold higher levels of IgM and marginal increases in IgG. In contrast, $\triangle \mathrm{BAFF}$ transgenics lack elevated (or reduced) IgA levels relative to wild type. While preliminary, this finding suggests that BAFF may have an especially significant, selective adjuvant effect on humoral mucosal immune responses. In addition, $\triangle \mathrm{BAFF}$ transgenics manifested a reduced level of plasma $\operatorname{IgG} 2 \mathrm{a} / \mathrm{b}$ and reductions in overall B cell numbers, particularly in the spleen where marginal zone B cell numbers were much lower (Table 2).

\section{Discussion}

While our analyses of BAFF and $\triangle \mathrm{BAFF}$ transgenic mice are still quite preliminary, our results are 
Table 2 Quantitation of Splenic Marginal Zone B Cell Numbers

\begin{tabular}{llll}
\hline \hline MZ cells* & $\begin{array}{l}\text { Littermate } \\
\text { controls }\end{array}$ & $\begin{array}{l}\text { Delta BAFF } \\
\text { Tg }\end{array}$ & BAFF Tg \\
\hline Mean (Std Dev) & $3.8(1.2) \times 10^{6}$ & $2.4(0.7) \times 10^{6}$ & $13.2(4.6) \times 10^{6}$ \\
$\mathrm{n}=$ & 15 & 13 & 11 \\
P value** & $\mathrm{N} / \mathrm{A}$ & $>0.001$ & $>0.0000001$ \\
\hline
\end{tabular}

* Phenotype defined by flow cytometry staining (B220+ CD21hi $\mathrm{CD} 2310)$. ** $\mathrm{P}$ value from two tailed, two sample equal variance Student's $\mathrm{T}$ Test comparing transgenic to control.

consistent with other studies indicating that BAFF overexpression can increase $\mathrm{B}$ cell numbers, and preferentially augment $\operatorname{IgA}$ and, to a lesser extent, IgM serum levels. ${ }^{57}$ Of greater novelty were the results using the $\triangle \mathrm{BAFF}$ expressing transgene. We had guessed that mice expressing this construct should suppress the effects of wild type BAFF, resulting in a phenotype resembling BAFF-deficient mice. ${ }^{48}$ Our results seem to confirm the prediction that $\triangle \mathrm{BAFF}$ expression partly neutralizes BAFF activity, because the $\triangle \mathrm{BAFF}$ overexpressing mice had the predicted reductions in $\mathrm{B}$ cell numbers. However, little reduction in serum $\operatorname{IgM}$ or $\operatorname{IgA}$ levels was seen relative to wild type mice. In contrast, IgG2a/b levels were reduced in $\triangle \mathrm{BAFF}$ transgenic mice. These results may suggest a role for $\triangle \mathrm{BAFF}$ in regulating isotype switch, antibody forming cell survival, or the expression of other cytokines that regulate these processes. Gorelik et al demonstrated that a major source of BAFF expression is radio resistant stromal cells. ${ }^{58}$ The CD68 expression of these is unknown and might explain why our $\triangle \mathrm{BAFF}$ transgenic mice do not more resemble a BAFF-deficient phenotype. So far, the most dramatic phenotype in $\triangle \mathrm{BAFF}$ transgenic mice has been the reduced numbers of marginal zone phenotype cells, perhaps reflecting the myeloid cell expression pattern of the transgenic promoter.

However, the phenotype of $\triangle \mathrm{BAFF}$ transgenics might be based not only on the ability of $\triangle \mathrm{BAFF}$ to act as a dominant negative of BAFF in CD68 positive cells; $\triangle \mathrm{BAFF}$ subunits might associate with other TNF family proteins, such as APRIL, or form homotrimers with unique biological functions. $\triangle \mathrm{BAFF}$ homomultimers can form and be transported to the plasma membrane of transfected 293 cells or S17 stromal cells. ${ }^{55}$

Acknowledgements: The authors thank Professor Masayuki Amagai for the lecture invitation, David Greaves for providing the CD68 promoter construct, and the National Institutes of Health for financial support (RO1GM44809 and P01AG01743).

\section{References}

1. Bretscher P, Cohn M: A theory of self-nonself discrimination. Science 1970; 169: 1042-1049
2. Klinman NR: The "clonal selection hypothesis" and current concepts of B cell tolerance. Immunity 1996; 5: 189-195

3. Tiegs SL, Russell DM, Nemazee D: Receptor editing in selfreactive bone marrow B cells. J Exp Med 1993; 177: 1009-1020

4. Hertz M, Nemazee D: BCR ligation induces receptor editing in $\operatorname{IgM}+\operatorname{IgD}$-bone marrow B cells in vitro. Immunity 1997; 6: 429-436

5. Melamed D, Benschop RJ, Cambier JC, Nemazee D: Developmental regulation of $\mathrm{B}$ lymphocyte immune tolerance compartmentalizes clonal selection from receptor selection. Cell 1998; 92: 173-182

6. Monroe JG: Tolerance sensitivity of immature-stage B cells: can developmentally regulated B cell antigen receptor (BCR) signal transduction play a role? J Immunol 1996; 156: 2657-2660

7. Mosier DE, Mond JJ, Goldings EA: The ontogeny of thymic independent antibody responses in vitro in normal mice and mice with an X-linked B cell defect. J Immunol 1977; 119: 1874-1878

8. Finkelman FD, Holmes JM, Dukhanina OI, Morris SC: Crosslinking of membrane immunoglobulin $\mathrm{D}$, in the absence of $\mathrm{T}$ cell help, kills mature B cells in vivo. J Exp Med 1995; 181: 515-525

9. Kouskoff V, Lacaud G, Nemazee D: T cell-independent rescue of B lymphocytes from peripheral immune tolerance. Science 2000; 287: 2501-2503

10. Murakami M, Tsubata T, Okamoto M, Shimizu A, Kumagai S, Imura H, Honjo T: Antigen-induced apoptotic death of Ly-1 B cells responsible for autoimmune disease in transgenic mice. Nature 1992; 357: 77-80

11. Russell DM, Dembic Z, Morahan G, Miller JF, Burki K, Nemazee D: Peripheral deletion of self-reactive B cells. Nature 1991; 354: $308-311$

12. Tsubata T, Murakami M, Honjo T: Antigen-receptor crosslinking induces peritoneal B-cell apoptosis in normal but not autoimmunity-prone mice. Curr Biol 1994; 4: 8-17

13. Goodnow CC, Crosbie J, Jorgensen H, Brink RA, Basten A: Induction of self-tolerance in mature peripheral B lymphocytes. Nature 1989; 342: 385-391

14. Grusby MJ, Auchincloss H Jr, Lee R, Johnson RS, Spencer JP, Zijlstra M, Jaenisch R, Papaioannou VE, Glimcher LH: Mice lacking major histocompatibility complex class I and class II molecules. Proc Natl Acad Sci USA 1993; 90: 3913-3917

15. Szomolanyi-Tsuda E, Welsh RM: T cell-independent antibodymediated clearance of polyoma virus in T cell-deficient mice. $\mathrm{J}$ Exp Med 1996; 183: 403-411

16. Nemazee D, Gavin A: Do B cells take advantage of 'missing self' recognition? Curr Dir Autoimmun 2003; 6: 245-264

17. Karre K: Natural killer cells and the MHC class I pathway of peptide presentation. Semin Immunol 1993; 5: 127-145

18. Lanier LL: On guard - activating NK cell receptors. Nat Immunol 2001; 2: 23-27

19. Barten R, Torkar M, Haude A, Trowsdale J, Wilson MJ: Divergent and convergent evolution of NK-cell receptors. Trends Immunol 2001; 22: 52-57

20. Blery M, Kubagawa H, Chen CC, Vely F, Cooper MD, Vivier E: The paired Ig-like receptor PIR-B is an inhibitory receptor that recruits the protein-tyrosine phosphatase SHP-1. Proc Natl Acad Sci USA 1998; 95: 2446-2451

21. Ho LH, Uehara T, Chen CC, Kubagawa H, Cooper MD: Constitutive tyrosine phosphorylation of the inhibitory paired Ig-like receptor PIR-B. Proc Natl Acad Sci USA 1999; 96: 15086-15090

22. Cornall RJ, Cyster JG, Hibbs ML, Dunn AR, Otipoby KL, Clark EA, Goodnow CC: Polygenic autoimmune traits: Lyn, CD22, and SHP-1 are limiting elements of a biochemical pathway regulating BCR signaling and selection. Immunity 1998; 8: 497-508

23. Nitschke L, Carsetti R, Ocker B, Kohler G, Lamers MC: CD22 is a negative regulator of B-cell receptor signalling. Curr Biol 1997; 7: 133-143 
24. Lanier LL: NK cell receptors. Annu Rev Immunol 1998; 16: 359-393

25. Miller I, Hatzivassiliou G, Cattoretti G, Mendelsohn C, DallaFavera R: IRTAs: a new family of immunoglobulinlike receptors differentially expressed in B cells. Blood 2002; 99: 2662-2669

26. Okazaki T, Maeda A, Nishimura H, Kurosaki T, Honjo T: PD-1 immunoreceptor inhibits B cell receptor-mediated signaling by recruiting src homology 2-domain-containing tyrosine phosphatase 2 to phosphotyrosine. Proc Natl Acad Sci USA 2001; 98: 13866-13871

27. Wilkinson R, Lyons AB, Roberts D, Wong MX, Bartley PA, Jackson DE: Platelet endothelial cell adhesion molecule-1 (PECAM-1/CD31) acts as a regulator of B-cell development, Bcell antigen receptor (BCR)-mediated activation, and autoimmune disease. Blood 2002; 100: 184-193

28. Otipoby KL, Draves KE, Clark EA: CD22 regulates B cell receptor-mediated signals via two domains that independently recruit Grb2 and SHP-1. J Biol Chem 2001; 276: 44315-44322

29. Fong DC, Brauweiler A, Minskoff SA, Bruhns P, Tamir I, Mellman I, Daeron M, Cambier JC: Mutational analysis reveals multiple distinct sites within $\mathrm{Fc}$ gamma receptor IIB that function in inhibitory signaling. J Immunol 2000; 165: 4453-4462

30. Davis RS, Wang YH, Kubagawa H, Cooper MD: Identification of a family of $\mathrm{Fc}$ receptor homologs with preferential B cell expression. Proc Natl Acad Sci USA 2001; 98: 9772-9777

31. Reth $\mathrm{M}$, Wienands $\mathrm{J}$ : Initiation and processing of signals from the B cell antigen receptor. Annu Rev Immunol 1997; 15: 453 479

32. Kubagawa H, Chen CC, Ho LH, Shimada TS, Gartland L, Mashburn C, Uehara T, Ravetch JV, Cooper MD: Biochemical nature and cellular distribution of the paired immunoglobulinlike receptors, PIR-A and PIR-B. J Exp Med 1999; 189: 309-318

33. Bendelac A: Mouse NK1+T cells. Curr Opin Immunol 1995; 7: 367-374

34. Bauer S, Groh V, Wu J, Steinle A, Phillips JH, Lanier LL, Spies $\mathrm{T}$ : Activation of NK cells and T cells by NKG2D, a receptor for stress-inducible MICA. Science 1999; 285: 727-729

35. Chen CC, Hurez V, Brockenbrough JS, Kubagawa $\mathrm{H}$, Cooper MD: Paternal monoallelic expression of the paired immunoglobulin-like receptors PIR-A and PIR-B. Proc Natl Acad Sci USA 1999; 96: 6868-6872

36. Fishelson Z, Donin N, Zell S, Schultz S, Kirschfink M: Obstacles to cancer immunotherapy: expression of membrane complement regulatory proteins (mCRPs) in tumors. Mol Immunol 2003; 40: $109-123$

37. Okazaki T, Tanaka Y, Nishio R, Mitsuiye T, Mizoguchi A, Wang $\mathrm{J}$, Ishida M, Hiai H, Matsumori A, Minato N, et al: Autoantibodies against cardiac troponin I are responsible for dilated cardiomyopathy in PD-1-deficient mice. Nat Med 2003; 9: $1477-$ 1483

38. Carlsson L, Candeias S, Staerz U, Keller G: Expression of Fc gamma RIII defines distinct subpopulations of fetal liver B cell and myeloid precursors. Eur J Immunol 1995; 25: 2308-2317

39. Farrell H, Degli-Esposti M, Densley E, Cretney E, Smyth M, Davis-Poynter N: Cytomegalovirus MHC class I homologues and natural killer cells: an overview. Microbes Infect 2000; 2: 521532

40. Chapman TL, Heikeman AP, Bjorkman PJ: The inhibitory receptor LIR-1 uses a common binding interaction to recognize class I MHC molecules and the viral homolog UL18. Immunity 1999; 11: 603-613

41. Beaufils P, Choquet D, Mamoun RZ, Malissen B: The (YXXL/ I) 2 signalling motif found in the cytoplasmic segments of the bovine leukaemia virus envelope protein and Epstein-Barr virus latent membrane protein $2 \mathrm{~A}$ can elicit early and late lymphocyte activation events. EMBO J 1993; 12: 5105-5112
42. Schmidt KN, Cyster JG: Follicular exclusion and rapid elimination of hen egg lysozyme autoantigen-binding B cells are dependent on competitor B cells, but not on T cells. J Immunol 1999; 162: $284-291$

43. Lang J, Nemazee D: B cell clonal elimination induced by membrane-bound self-antigen may require repeated antigen encounter or cell competition. Eur J Immunol 2000; 30: 689-696

44. Lam KP, Kuhn R, Rajewsky K: In vivo ablation of surface immunoglobulin on mature B cells by inducible gene targeting results in rapid cell death. Cell 1997; 90: 1073-1083

45. Mackay F, Schneider P, Rennert P, Browning J: BAFF AND APRIL: a tutorial on B cell survival. Annu Rev Immunol 2003; 21: $231-264$

46. Mond JJ, Lees A, Snapper CM: T cell-independent antigens type 2. Annu Rev Immunol 1995; 13: 655-692

47. Do RK, Hatada E, Lee H, Tourigny MR, Hilbert D, Chen-Kiang S: Attenuation of apoptosis underlies B lymphocyte stimulator enhancement of humoral immune response. J Exp Med 2000; 192: 953-964

48. Schiemann B, Gommerman JL, Vora K, Cachero TG, ShulgaMorskaya S, Dobles M, Frew E, Scott ML: An essential role for BAFF in the normal development of B cells through a BCMAindependent pathway. Science 2001; 293: 2111-2114

49. Mackay F, Woodcock SA, Lawton P, Ambrose C, Baetscher M, Schneider P, Tschopp J, Browning JL: Mice transgenic for BAFF develop lymphocytic disorders along with autoimmune manifestations. J Exp Med 1999; 190: 1697-1710

50. Khare SD, Sarosi I, Xia XZ, McCabe S, Miner K, Solovyev I, Hawkins N, Kelley M, Chang D, Van G, et al: Severe B cell hyperplasia and autoimmune disease in TALL-1 transgenic mice. Proc Natl Acad Sci USA 2000; 97: 3370-3375

51. Gross JA, Dillon SR, Mudri S, Johnston J, Littau A, Roque R, Rixon M, Schou O, Foley KP, Haugen H, et al: TACI-Ig neutralizes molecules critical for B cell development and autoimmune disease. impaired $\mathrm{B}$ cell maturation in mice lacking BLyS. Immunity 2001; 15: 289-302

52. Yan M, Brady JR, Chan B, Lee WP, Hsu B, Harless S, Cancro M, Grewal IS, Dixit VM: Identification of a novel receptor for B lymphocyte stimulator that is mutated in a mouse strain with severe B cell deficiency. Curr Biol 2001; 11: 1547-1552

53. Rahman ZS, Rao SP, Kalled SL, Manser T: Normal induction but attenuated progression of germinal center responses in BAFF and BAFF-R signaling-deficient mice. J Exp Med 2003; 198: $1157-1169$

54. Thompson JS, Schneider P, Kalled SL, Wang L, Lefevre EA, Cachero TG, MacKay F, Bixler SA, Zafari M, Liu ZY, et al: $\mathrm{BAFF}$ binds to the tumor necrosis factor receptor-like molecule $B$ cell maturation antigen and is important for maintaining the peripheral B cell population. J Exp Med 2000; 192: 129-135

55. Gavin AL, Ait-Azzouzene D, Ware CF, Nemazee D: Delta$\mathrm{BAFF}$, an alternate splice isoform that regulates receptor binding and biopresentation of the B cell survival cytokine, BAFF. J Biol Chem 2003; 278: 38220-38228

56. Gough PJ, Gordon S, Greaves DR: The use of human CD68 transcriptional regulatory sequences to direct high-level expression of class A scavenger receptor in macrophages in vitro and in vivo. Immunology 2001; 103: 351-361

57. Parry TJ, Riccobene TA, Strawn SJ, Williams R, Daoud R, Carrell J, Sosnovtseva S, Miceli RC, Poortman CM, Sekut L, et al: Pharmacokinetics and immunological effects of exogenously administered recombinant human B lymphocyte stimulator (BLyS) in mice. J Pharmacol Exp Ther 2001; 296: 396-404

58. Gorelik L, Gilbride K, Dobles M, Kalled SL, Zandman D, Scott ML: Normal B cell homeostasis requires B cell activation factor production by radiation-resistant cells. J Exp Med 2003; 198: 937-945 
59. Watanabe-Fukunaga R, Brannan CI, Copeland NG, Jenkins NA, Nagata S: Lymphoproliferation disorder in mice explained by defects in Fas antigen that mediates apoptosis. Nature 1992; 356: $314-317$

60. Prodeus AP, Goerg S, Shen LM, Pozdnyakova OO, Chu L, Alicot EM, Goodnow CC, Carroll MC: A critical role for complement in maintenance of self-tolerance. Immunity 1998; 9: 721-731

61. Kozono Y, Duke RC, Schleicher MS, Holers VM: Co-ligation of mouse complement receptors 1 and 2 with surface $\operatorname{IgM}$ rescues splenic B cells and WEHI-231 cells from anti-surface IgMinduced apoptosis. Eur J Immunol 1995; 25: 1013-1017

62. Parry SL, Hasbold J, Holman M, Klaus GG: Hypercross-linking surface IgM or IgD receptors on mature B cells induces apoptosis that is reversed by costimulation with IL-4 and anti-CD40. J Immunol 1994; 152: 2821-2829

63. Tsubata T, Wu J, Honjo T: B-cell apoptosis induced by antigen receptor crosslinking is blocked by a T-cell signal through CD40. Nature 1993; 364: 645-648

64. Bolland S, Ravetch JV: Spontaneous autoimmune disease in $\mathrm{Fc}$ (gamma)RIIB-deficient mice results from strain-specific epistasis. Immunity 2000; 13: 277-285

65. Hibbs ML, Tarlinton DM, Armes J, Grail D, Hodgson G, Maglitto R, Stacker SA, Dunn AR: Multiple defects in the immune system of Lyn-deficient mice, culminating in autoimmune disease. Cell 1995; 83: 301-311

66. Chan VW, Meng F, Soriano P, DeFranco AL, Lowell CA: Characterization of the B lymphocyte populations in Lyndeficient mice and the role of Lyn in signal initiation and downregulation. Immunity 1997; 7: 69-81

67. Nishizumi H, Taniuchi I, Yamanashi Y, Kitamura D, Ilic D, Mori $\mathrm{S}$, Watanabe T, Yamamoto T: Impaired proliferation of peripheral B cells and indication of autoimmune disease in lyn-deficient mice. Immunity 1995; 3: 549-560

68. Kozlowski M, Mlinaric-Rascan I, Feng GS, Shen R, Pawson T, Siminovitch KA: Expression and catalytic activity of the tyrosine phosphatase PTP1C is severely impaired in motheaten and viable motheaten mice. J Exp Med 1993; 178: 2157-2163

69. Tsui HW, Siminovitch KA, de Souza L, Tsui FW: Motheaten and viable motheaten mice have mutations in the haematopoietic cell phosphatase gene. Nat Genet 1993; 4: 124-129

70. O'Keefe TL, Williams GT, Batista FD, Neuberger MS: Deficiency in $\mathrm{CD} 22$, a B cell-specific inhibitory receptor, is sufficient to predispose to development of high affinity autoantibodies. J Exp Med 1999; 189: 1307-1313

71. Sato S, Miller AS, Inaoki M, Bock CB, Jansen PJ, Tang ML, Tedder TF: CD22 is both a positive and negative regulator of $\mathrm{B}$ lymphocyte antigen receptor signal transduction: altered signaling in CD22-deficient mice. Immunity 1996; 5: 551-562

72. Lang J, Arnold B, Hammerling G, Harris AW, Korsmeyer S, Russell D, Strasser A, Nemazee D: Enforced Bcl-2 expression inhibits antigen-mediated clonal elimination of peripheral B cells in an antigen dose-dependent manner and promotes receptor editing in autoreactive, immature B cells. J Exp Med 1997; 186: $1513-1522$

73. Enders A, Bouillet $\mathrm{P}$, Puthalakath $\mathrm{H}, \mathrm{Xu} \mathrm{Y}$, Tarlinton DM, Strasser A: Loss of the pro-apoptotic BH3-only Bcl-2 family member Bim inhibits BCR stimulation-induced apoptosis and deletion of autoreactive B cells. J Exp Med 2003; 198: 11191126

74. Shinjyo T, Kuribara R, Inukai T, Hosoi H, Kinoshita T, Miyajima A, Houghton PJ, Look AT, Ozawa K, Inaba T: Downregulation of $\mathrm{Bim}$, a proapoptotic relative of $\mathrm{Bcl}-2$, is a pivotal step in cytokine-initiated survival signaling in murine hematopoietic progenitors. Mol Cell Biol 2001; 21: 854-864

75. Leadbetter EA, Rifkin IR, Hohlbaum AM, Beaudette BC, Shlomchik MJ, Marshak-Rothstein A: Chromatin-IgG complexes activate B cells by dual engagement of IgM and Toll-like receptors. Nature 2002; 416: 603-607

76. Seshasayee D, Valdez P, Yan M, Dixit VM, Tumas D, Grewal IS: Loss of TACI causes fatal lymphoproliferation and autoimmunity, establishing TACI as an inhibitory BLyS receptor. Immunity 2003; 18: 279-288

77. Lynch DH, Watson ML, Alderson MR, Baum PR, Miller RE, Tough T, Gibson M, Davis-Smith T, Smith CA, Hunter K, et al: The mouse Fas-ligand gene is mutated in gld mice and is part of a TNF family gene cluster. Immunity 1994; 1: 131-136

78. Takahashi T, Tanaka M, Brannan CI, Jenkins NA, Copeland NG, Suda T, Nagata S: Generalized lymphoproliferative disease in mice, caused by a point mutation in the Fas ligand. Cell 1994; 76: 969-976

79. Wu J, Wilson J, He J, Xiang L, Schur PH, Mountz JD: Fas ligand mutation in a patient with systemic lupus erythematosus and lymphoproliferative disease. J Clin Invest 1996; 98: 1107-1113

80. Botto M, Dell'Agnola C, Bygrave AE, Thompson EM, Cook HT, Petry F, Loos M, Pandolfi PP, Walport MJ: Homozygous C1q deficiency causes glomerulonephritis associated with multiple apoptotic bodies. Nat Genet 1998; 19: 56-59

81. Chen Z, Koralov SB, Kelsoe G: Complement C4 inhibits systemic autoimmunity through a mechanism independent of complement receptors CR1 and CR2. J Exp Med 2000; 192: $1339-1352$

82. Ma J, Xu J, Madaio MP, Peng Q, Zhang J, Grewal IS, Flavell RA, Craft J: Autoimmune lpr/lpr mice deficient in CD40 ligand: spontaneous Ig class switching with dichotomy of autoantibody responses. J Immunol 1996; 157: 417-426

83. Mohan C, Shi Y, Laman JD, Datta SK: Interaction between CD40 and its ligand gp39 in the development of murine lupus nephritis. J Immunol 1995; 154: 1470-1480

84. Higuchi T, Aiba Y, Nomura T, Matsuda J, Mochida K, Suzuki M, Kikutani H, Honjo T, Nishioka K, Tsubata T: Cutting Edge: Ectopic expression of CD40 ligand on B cells induces lupus-like autoimmune disease. J Immunol 2002; 168: 9-12

85. Foote LC, Marshak-Rothstein A, Rothstein TL: Tolerant B lymphocytes acquire resistance to Fas-mediated apoptosis after treatment with interleukin 4 but not after treatment with specific antigen unless a surface immunoglobulin threshold is exceeded. J Exp Med 1998; 187: 847-853

86. Morris SC, Dragula NL, Finkelman FD: IL-4 promotes Stat6dependent survival of autoreactive B cells in vivo without inducing autoantibody production. J Immunol 2002; 169: 16961704

87. Mariette X, Roux S, Zhang J, Bengoufa D, Lavie F, Zhou T, Kimberly R: The level of BLyS (BAFF) correlates with the titre of autoantibodies in human Sjögren's syndrome. Ann Rheum Dis 2003; 62: 168-171

88. Groom J, Kalled SL, Cutler AH, Olson C, Woodcock SA, Schneider P, Tschopp J, Cachero TG, Batten M, Wheway J, et al: Association of BAFF/BLyS overexpression and altered B cell differentiation with Sjögren's syndrome. J Clin Invest 2002; 109: 59-68

89. Phan TG, Amesbury M, Gardam S, Crosbie J, Hasbold J, Hodgkin PD, Basten A, Brink R: B cell receptor-independent stimuli trigger immunoglobulin (Ig) class switch recombination and production of $\mathrm{IgG}$ autoantibodies by anergic self-reactive B cells. J Exp Med 2003; 197: 845-860 